\title{
Knocking down gene expression for growth hormone-releasing hormone inhibits proliferation of human cancer cell lines
}

\author{
N Barabutis ${ }^{1,2}$ and AV Schally,1,2 \\ 'Veterans Affairs Medical Center and South Florida Veterans Affairs Foundation for Research and Education, Miami, FL 33125, USA; ${ }^{2}$ Department Of \\ Pathology and division of Hematology/Oncology, Department of Medicine, University of Miami, Miller School of Medicine, Miami, FL 33/25, USA
}

Splice Variant I (SV-I) of growth hormone-releasing hormone (GHRH) receptor, found in a wide range of human cancers and established human cancer cell lines, is a functional receptor with ligand-dependent and independent activity. In the present study, we demonstrated by western blots the presence of the SVI of GHRH receptor and the production of GHRH in MDA-MB-468, MDA-MB-435S and T47D human breast cancer cell lines, LNCaP prostate cancer cell line as well as in NCI H838 non-small cell lung carcinoma. We have also shown that GHRH produced in the conditioned media of these cell lines is biologically active. We then inhibited the intrinsic production of $\mathrm{GHRH}$ in these cancer cell lines using si-RNA, specially designed for human GHRH. The knocking down of the GHRH gene expression suppressed the proliferation of T47D, MDA-MB-435S, MDA-MB-468 breast cancer, LNCaP prostate cancer and $\mathrm{NCl} \mathrm{H} 838$ non-SCLC cell lines in vitro. However, the replacement of the knocked down GHRH expression by exogenous $\mathrm{GHRH}(\mathrm{I}-29) \mathrm{NH}_{2}$ re-established the proliferation of the silenced cancer cell lines. Furthermore, the proliferation rate of untransfected cancer cell lines could be stimulated by GHRH (I-29) $\mathrm{NH}_{2}$ and inhibited by GHRH antagonists MZ-5- I56, MZ-4-7 I and JMR-I32. These results extend previous findings on the critical function of GHRH in tumorigenesis and support the role of $\mathrm{GHRH}$ as a tumour growth factor.

British Journal of Cancer (2008) 98, I790- 1796. doi:I0.1038/sj.bjc.6604386 www.bjcancer.com

Published online 27 May 2008

(c) 2008 Cancer Research UK

Keywords: breast cancer; lung and prostate cancer; GHRH

Dysfunction of cell differentiation and cell cycle regulation define and promote carcinogenesis. Growth hormone-releasing hormone (GHRH) was first isolated from human pancreatic tumours and only subsequently identified in human and animal hypothalami (reviewed in Schally and Varga, 2006). The full intrinsic biological activity of GHRH is retained by the $\mathrm{NH}_{2}$-terminal 29 amino acid sequence. Growth hormone-releasing hormone is secreted by the hypothalamus and upon binding to the specific GHRH-Receptors (GHRH-R) on somatotrophs regulates the release of Growth Hormone $(\mathrm{GH})$ from the anterior pituitary gland. In turn, GH stimulates the production of insulin-like growth factor-I (IGF-I), which functions as a cell cycle stimulator (Macaulay, 1992; Westley and May, 1995).

Growth hormone-releasing hormone-receptors (GHRH-R) is a class II G protein-coupled receptor and contains seven transmembrane domains (Mayo, 1992). Growth hormone-releasing hormonereceptor is homologous with the receptors for the vasoactive intestinal peptide (VIP), the pituitary adenyl cyclase activating polypeptide and calcitonin (Gaylinn et al, 1993). Recently, peptide receptors that mediate the effects of GHRH and its antagonists on

\footnotetext{
*Correspondence: Dr AV Schally, Research Service (15I), Veterans Affairs Medical Center, I20I Northwest 16th Street, Miami, FL 33I25, USA; E-mail: andrew.schally@va.gov

Received 6 December 2007; revised 26 March 2008; accepted 27 March 2008; published online 27 May 2008
}

tumours were identified. The isolation and sequencing of cDNAs which correspond to the tumoral GHRH receptor mRNA revealed that they are splice variants (SVs) of the pituitary GHRH receptors (pGHRH-R) (Rekasi et al, 2000).

Splice variant 1 of GHRH receptor is a functional receptor, which differs from the pGHRH-R only in the N-terminal extracellular domains. The first 89 amino acids of the pGHRH-R are replaced in SV-1 receptor by a different 25-amino acid sequence (reviewed in Schally and Varga, 2006). Some tumours also express pituitary type of GHRH receptor (Havt et al, 2005; Christodoulou et al, 2006). Besides its ligand-dependent activity, a ligand-independent activity of SV1 has also been demonstrated (Kiaris et al, 2003). A recent study showed the stimulation and proliferation of MCF-7 breast cancer cells after the transfection of SV1 (Barabutis et al, 2007). The expression of mRNA for GHRH and the presence of biologically or immunologically active GHRH were demonstrated in several established cancer cell lines and human tumours. Collectively, those data suggest that GHRH may function as a growth factor among a large class of mitogens involved in tumorigenesis. In an endeavour to develop new methods for cancer treatment, we developed the antagonists of GHRH (reviewed in Schally and Varga, 2006).

Growth hormone-releasing hormone antagonists suppress the in vivo growth of various experimental cancers such as prostatic (Zarandi et al, 2006; Stangelberger et al, 2007), mammary (Buchholz et al, 2007), ovarian (Chatzistamou et al, 2001), renal cell carcinomas (Halmos et al, 2000), small cell lung carcinomas 
(Hohla et al, 2006), pancreatic and colorectal carcinomas (Szepeshazi et al, 2000; Busto et al, 2002), endometrial (Engel et al, 2005), osteogenic sarcomas (Braczkowski et al, 2002) as well as malignant glioblastomas (Jaeger et al, 2005).

The inhibitory effect of antagonistic analogues of GHRH is exerted in part by endocrine mechanisms through the suppression of GHRH-evoked GH release from the pituitary, which, in turn results in the reduction of hepatic production of IGF-I and a decrease in the serum IGF-I levels. The anti-tumour effects of GHRH antagonists can be also mediated through direct mechanisms. One of these mechanisms is based upon the inhibition of the secretion of autocrine/paracrine IGF-I or IGF-II from the tumours, while probably the most important pathway involves the blockade of action of autocrine GHRH in tumours. The antitumour activity of our GHRH antagonists is especially important oncologically because of the wide expression of the intrinsic GHRH, pGHRH-R and SVs of GHRH-R in various cancers.

In the present study, we evaluated by western blot the expression of the SV-1 of GHRH-R and its GHRH ligand in human breast cancer (MDA-MB-468, MDA-MB-435S, T47D), prostate cancer (LNCaP) and non-SCLC (NCI H838) cell lines. We detected the GHRH produced in the conditioned medium of these cell lines. To further elucidate the role of GHRH in carcinogenesis, we knocked down the gene expression of GHRH. In addition, we examined the effect of GHRH and GHRH antagonists MZ-4-71, MZ-5-156 and JMR-132 at two dose levels on the proliferation rate of the cited cancer cell lines. Our results demonstrate the critical function of GHRH and its receptors in tumorigenesis.

\section{MATERIALS AND METHODS}

\section{Peptides and chemicals}

Growth hormone-releasing hormone antagonists JMR-132 [ $\mathrm{PhAc}^{0}$, $\mathrm{DArg}^{2}$, Phe $(4-\mathrm{C})^{6}, \mathrm{Ala}^{8}, \mathrm{Har}^{9}, \mathrm{Tyr}(\mathrm{Me})^{10}, \mathrm{His}^{11}, \mathrm{Abu}^{15}, \mathrm{His}^{20}$, $\mathrm{Nle}^{29}$, D-Arg ${ }^{28}, \mathrm{Har}^{29}$ ] human GHRH $(1-29) \mathrm{NH}_{2}, \mathrm{MZ}-5-156$ [PhAc-Tyr ${ }^{1}$, D-Arg ${ }^{2}$, Phe (4-CI) ${ }^{6}, \mathrm{Abu}^{15}, \mathrm{Nle}^{27}$ hGHRH $(1-28)$ Agm and MZ-4-71 [Ibu-Tyr ${ }^{1}, \mathrm{D}-\mathrm{Arg}^{2}, \mathrm{Phe}(4-\mathrm{CI})^{6}, \mathrm{Abu}^{15}$, $\mathrm{NIe}^{27}$ ] hGHRH $(1-28)$ Agm, where Abu is a-aminobutyric acid, Agm is agmatine, Har is homoarginine, Nle is norleucine, PhAc is phenylacetyl and $\operatorname{Tyr}(\mathrm{Me})$ is $O$-methyltyrosine were synthesized in our laboratory by solid phase methods $(1,19)$. Growth hormonereleasing hormone $(1-29) \mathrm{NH}_{2}$ and $\mathrm{GHRH}$ antagonists were dissolved in $0.1 \%$ DMSO and diluted with incubation media.

\section{Cell culture}

The cell lines (LNCaP, MCF-7, MDA-MB-468, MDA-MB-435s, T47D, and NCI-H838) were obtained from American Type Culture Collection (Manassas, VA, USA) and cultured at $37^{\circ} \mathrm{C}$ in a humidified $95 \%$ air $/ 5 \% \mathrm{CO}_{2}$ atmosphere. Breast cancer cell lines MCF-7, MDA-MB-468, MDA-MB-435s and T47D were cultured in DMEM supplemented with antibiotics/antimycotics and 10\% FBS. Prostate cancer cell line (LNCaP) and non SCLC cell line NCI H838 were cultured in RPMI-1640 supplemented with antibiotics/ antimycotics and $10 \%$ fetal bovine serum (FBS). The culture media were purchased from GIBCO (Carlsbad, CA).

\section{Protein isolation and western blot assay}

The expression of GHRH and SV1 receptor was assessed by western blot in T47D, MDA-MB-435s, MDA-MB-468 breast cancer cell lines, LNCaP prostate cancer line and NCI H838 non-SCLC line. MCF-7 breast cancer cell line which does not produce either GHRH or SV1 receptor was used as negative control (Barabutis et $a l, 2007)$. The proteins were isolated from the cells using CelyticM Lysis Reagent (Sigma, St Louis, MO, USA) and the concentration of the isolated proteins was determined by Quickstart Bradford Protein Assay (Bio-Rad, Hercules, CA, USA) according to manufacturer's instructions. Protein matched samples (15 $\mathrm{g}$ per lane) were separated by electrophoresis 12.5 or 8-16\% sodium dodecyl sulphate (SDS-PAGE Tris-HCL precast gels (Bio-Rad, Hercules, CA, USA). Electroblotting was used to transfer the proteins onto nitrocellulose membranes (Biorad, Hercules, CA, USA). The membranes were incubated for $3 \mathrm{~h}$ at room temperature in $5 \%$ non fat dry milk in phosphate-buffered saline (PBS) $-0.1 \%(\mathrm{v} / \mathrm{v})$ Tween 20 . The blots were then incubated at $4{ }^{\circ} \mathrm{C}$ overnight with an affinity purified goat polyclonal antibody against a peptide mapping near the $\mathrm{N}$ terminus of GHRH of human origin $(1: 425)$ (cat no. 10280, Santa Cruz Biotechnology, Santa Cruz, CA, USA) and with rabbit antiserum to SV1 $(1: 2000)$ raised in our laboratory (Toller et al, 2004). The antiserum batch number for SV1 was $\mathrm{JH} 2317 / 5$. The signal for the immunoreactive proteins was developed with peroxidase-conjugated secondary antibodies (Santa Cruz and Cell Signalling, Danvers, MA, USA) and visualised by exposure to chemiluminescence substrate (Amersham Biotechnologies, Piscataway, NJ, USA). The $\beta$-actin signal (1:1000, Santa Cruz) was used as control.

\section{Quantitative analysis of the immunoblot assay}

The protein bands signals were quantified by Adobe Photoshop and normalised to $\beta$-actin signal. The intensity of the bands was equal to their mean value multiplied by their pixel value (absolute intensity). Relative intensity (RI) of each band is calculated by dividing its absolute intensity by the absolute intensity of the control band ( $\beta$-actin). The percentage efficiency of the knocking down of the GHRH gene expression was calculated as \{(R.I of the Pre-pro GHRH band of untransfected cells - RI of the pre-pro GHRH band of transfected cells)/RI of the Pre-pro GHRH band of untransfected cells $\} \times 100$.

\section{Radioimmunoassay of GHRH}

Tumour cells $\left(3 \times 10^{5}\right.$ cells $)$ were seeded in 48 -well petri dishes and allowed to attach for $24 \mathrm{~h}$ when the media were replaced by serumfree medium (SFM). Aliquots of $0.1 \mathrm{ml}$ medium from MCF-7, T47D, MDA-MB-435s, MDA-MB-468 breast cancer cell lines, LNCaP prostate cancer cell line and NCI H838 non-SCLC cell line growing for $0,24,48$ and $72 \mathrm{~h}$ were assayed for GHRH immunoreactivity. Growth hormone-releasing hormone was measured by using ([ $\left.{ }^{125} \mathrm{I}\right]-\mathrm{Tyr}$ )-GHRH-]) (human) (Bachem, cat no. H-5028) as the labelled peptide and a rabbit antibody against GHRH $(1-44) \mathrm{NH}_{2}$ (Bachem, cat no. S 2027). This antibody crossreacts $100 \%$ with human GHRH $(1-44) \mathrm{NH}_{2}$ and $30 \%$ with human GHRH $(1-29) \mathrm{NH}_{2}$. Growth hormone-releasing hormone $(1-44) \mathrm{NH}_{2}$ (Bachem, cat no. $\mathrm{H}-3695)$ was used as a standard. The range was $1-128$ pg per tube.

\section{Transfection}

Small interfering (si) RNA designed specially for the inhibition of the human GHRH was used to knock down the GHRH gene expression of the T47D, MDA-MB-435s, MDA-MB-468 breast cancer cell lines, LNCaP prostate cancer cell line and NCI H838 non-SCLC cell line. A pool of three oligonucleotides especially designed for the inhibition of the human GHRH (sc39519, Santa Cruz Biotechnology) and cationic liposomes (Lipofectamine, Invitrogen, Carlsbad, CA, USA) were used to knock down the gene expression of the GHRH. The sequence of the sense strand (a) was GGUAUGCAGAUGCCAUCUUTT and the mRNA location is 92. The sequence of the sense strand (b) was CCAGUUAAUCCUCU CAUUUTT and its mRNA location is 376 . The sequence of the sense strand (c) was CCAGUUAAUCCUCUCAUUUTT and its mRNA location is 434. RNA that does not lead to any specific degradation of any known cellular mRNA (control siRNA, sc37007, 
Santa Cruz Biotechnology) was used as control. The sequence of the sense strand was UUCUCCGAACGUGUCACGU. One day before the transfection, the cells were plated in six-well plates in $2 \mathrm{ml}$ of growth media without antibiotics to be $40 \%$ confluent on the day of transfection. For the transfection $40-60 \mathrm{~nm}$ siRNA was diluted in $0.25 \mathrm{ml}$ Opti-MEM I Reduced Serum Medium (Invitrogen, Carlsbad, CA, USA) without serum and $5 \mu$ l lipofectamine 2000 were diluted in an equal volume of Opti-MEM I. After incubation for $5 \mathrm{~min}$ at room temperature, the diluted oligomers were combined with the lipofectamine 2000 and incubated for $30 \mathrm{~min}$ also in room temperature. The oligomer-lipofectamine complexes were added to each well, which contained $2 \mathrm{ml}$ of medium without antibiotics. The medium was changed $8 \mathrm{~h}$ after transfection. The cells were incubated at $37^{\circ} \mathrm{C}$ in an atmosphere of $5 \% \mathrm{CO}_{2}$ and $95 \%$ air for $48-72 \mathrm{~h}$ after transfection and then assayed by western blot for gene knockdown.

\section{Cell proliferation rate assay}

The rate of the cell proliferation was calculated by seeding 10000 cells in six-well plates and after an incubation for 4 days counting them under light microscope using the trypan blue assay.

\section{Statistical analysis}

These data are expressed as the mean \pm s.e.m. Statistical evaluation of the results was performed by the Student's $t$-test (two-tailed). $P$-values shown are against the control group.

\section{RESULTS}

Expression of growth hormone releasing hormone and splice variant 1 of the GHRH receptor in breast and prostate cancer and non-SCLC cell lines

A band of $45 \mathrm{KDa}$ which reflects the production of pre-pro GHRH (Othman et al, 2001) was detected in all the cancer cell lines examined. The results are shown in Figure 1. Pre-pro GHRH protein expression was the highest in T47D (R.I:0.464), followed by MDA-MB-435s (R.I:0.449), NCI H838 (R.I:0.437), MDA-MB-468 (R.I:0.312) and LNCaP (R.I:0.193). A band at $39.5 \mathrm{KDa}$ which is consistent with the size of the SV1 receptor (Havt et al, 2005) was also detected in all the cancer cell lines examined. The results are shown in Figure 2. The levels of the SV1 GHRH-R protein were the highest in T47D (R.I:0.696), followed by NCI H838 (R.I:0.376), MDA-MB-435s (R.I:0.316), LNCaP (R.I:0.169), MDA-MB-468 (R.I:0.160).

Detection of the secretion of growth hormone-releasing hormone in the conditioned medium of the cancer cell lines by radioimmunoassay

The concentration of the GHRH in samples from culture medium was measured by RIA. Significant amounts of GHRH were detected in the medium from T47D $\left(1.518,2.083,0.266 \mathrm{ng} \mathrm{ml}^{-1}\right)$, NCI H838(0.303, $\left.0.442,0.689 \mathrm{ng} \mathrm{ml}^{-1}\right), \quad \mathrm{MDA}-\mathrm{MB}-435 \mathrm{~s} \quad(0.675,1.036$, $\left.1.442 \mathrm{ng} \mathrm{ml}^{-1}\right), \operatorname{LNCaP}\left(0.202,0.218,0.208 \mathrm{ng} \mathrm{ml}^{-1}\right)$, and MDA-MB$46 \mathrm{ng} \mathrm{ml}^{-1}(0.637,0.816,0.649)$ cell lines after 24,48 and $72 \mathrm{~h}$ respectively as shown in Table 1 . Growth hormone-releasing hormone was not detected either in the cultured medium without cells or in the conditioned medium of the MCF7 breast cancer cell line.

Inhibition of the GHRH gene expression in breast, prostate and non-SLCL cancer cell lines and its effect on proliferation

The effective inhibition of the GHRH gene expression was confirmed by western blot. The results are seen in Figure 3. The GHRH expression in the transfected NCI H838, LNCaP, T47D cell lines was suppressed by 85,85 and $92 \%$ respectively. The decreased proliferation rate of the MDA-MB-468 and MDA-MB$435 \mathrm{~s}$ cell lines did not allow us to isolate protein from those cells during early cell passages. Since the silencing of the gene expression for GHRH lasts only for limited cell passages, the western blots of the proteins obtained in late cell passages show

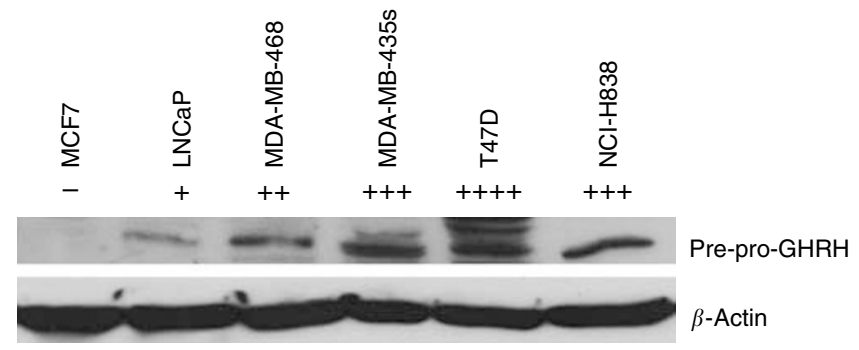

Figure I Western blot analysis of protein expression of $\mathrm{GHRH}$ in breast cancer (MCF-7, MDA-MB-468, MDA-MB-435s, T47D), lung cancer (NCl-H838) and prostate cancer (LNCaP) cell lines. MCF-7 breast cancer cell line was used as negative control. Signal intensity of the $45 \mathrm{kDa}$ precursor GHRH protein is indicated by the symbol + . Protein levels were normalised to $\beta$-actin signal.

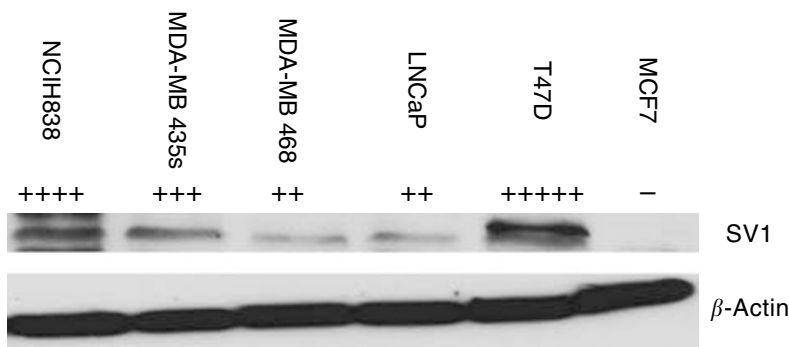

Figure 2 Western blot analysis of expression of SVI in breast cancer (MCF-7, MDA-MB-468, MDA-MB-435s, T47D), lung cancer (NCl-H838) and prostate cancer (LNCaP) cell lines. MCF-7 breast cancer cell line was used as negative control. Signal intensity of $\mathrm{GHRH}$ protein is indicated by the symbol + . Protein levels were normalised to $\beta$-actin signal.

Table I Production of GHRH in culture medium from human breast cancer (MCF-7, MDA-MB-468, MDA-MB-435S, T47D) prostate cancer (LNCaP) and non-small cell lung carcinoma ( $\mathrm{NCl} \mathrm{H838)} \mathrm{cell} \mathrm{lines}$

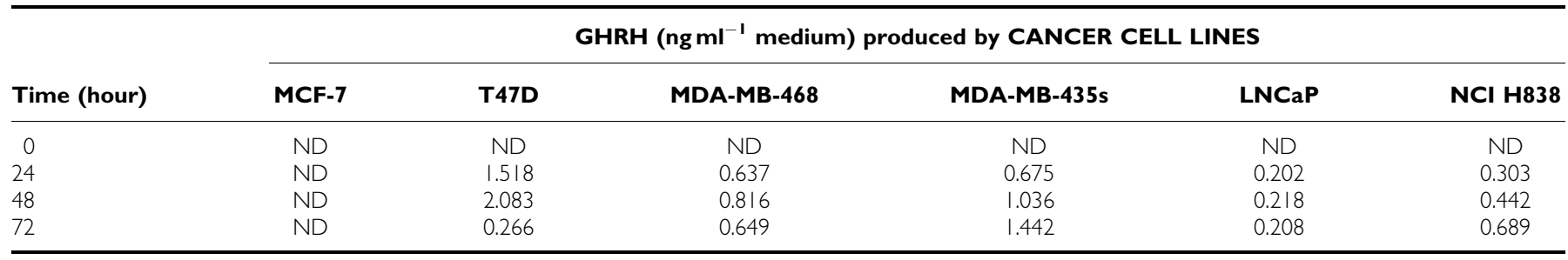

$\mathrm{ND}=$ not detectable. Aliquots of medium were subjected to RIA for the detection of GHRH at the indicated periods of time. 


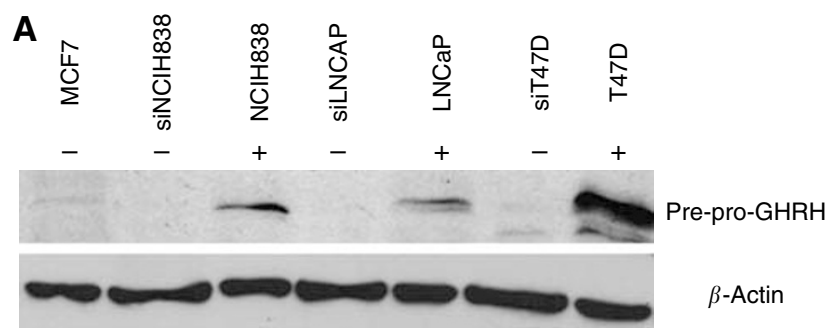

B

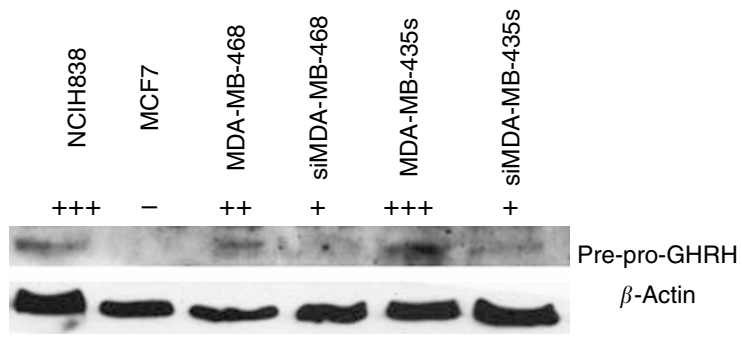

Figure 3 Western blot analysis of GHRH in cancer cell lines before and after the inhibition of the GHRH gene expression. The knocked down cells are marked as si. MCF-7 breast cancer cell line was used as negative control. Protein levels were normalised to $\beta$-actin signal. (A) The detection of the GHRH protein expression in breast (T47D), lung (NCl-H838) and prostate cancer (LNCaP) cell lines. (B) The detection of the GHRH protein expression in breast cancer (MDA-MB-468, MDA-MB-435s) cell lines. $\mathrm{NClH}-838$ cancer cell line was used as positive control. Signal intensity of GHRH protein is indicated by the symbol + . Protein levels were normalised to $\beta$-actin signal.

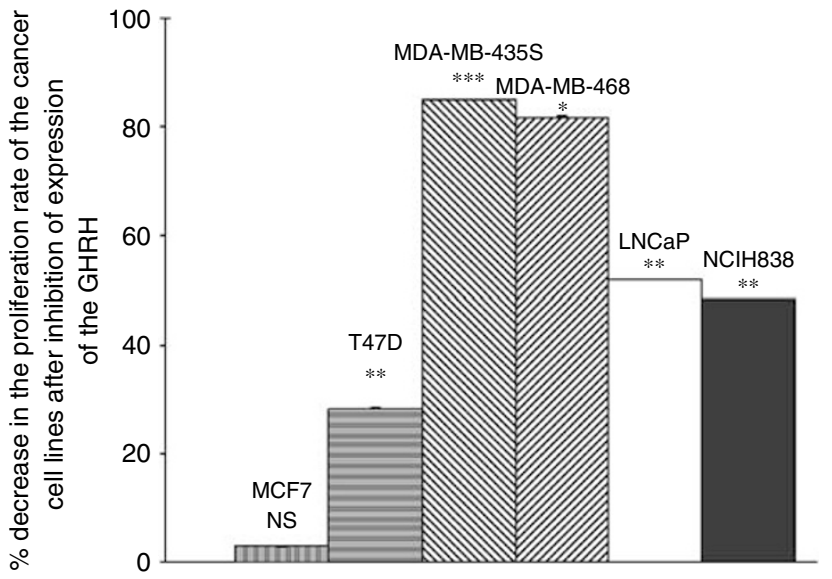

Figure 4 Graphic presentation of the decrease in the proliferation rate of the MBA-MB-468, MDA-MB-435s T47D, LNCaP and NCl H838 after the knocking down of the expression of the ectopic GHRH. MCF-7 breast cancer cell line was used as control. Vertical bars represent s.e.m. Data are representative of one experiment in triplicate in each case. Percentage decrease and signalling are expressed vs corresponding untreated cells. $* P<0.05$, ** $P<0.005$, *** $P<0.001$.

that the silencing of the GHRH gene expression was less effective for the two breast cancer cell lines in these passages (28 and 64\% respectively). After the knocking down of GHRH expression, the proliferation rate of the T47D, MDA-MB-435s, MDA-MB-468, LNCaP, NCI H838 human cancer cell lines was decreased by 28.3, $85.9,85.1,51.8$ and $48.4 \%$ respectively (Figure 4 ). The transfection of siRNA for GHRH did not influence the proliferation rate of MCF-7 cells. We also used control siRNA, which contains a scrambled sequence that does not lead to the specific degradation of any known cellular mRNA for transfection of all cell lines. No

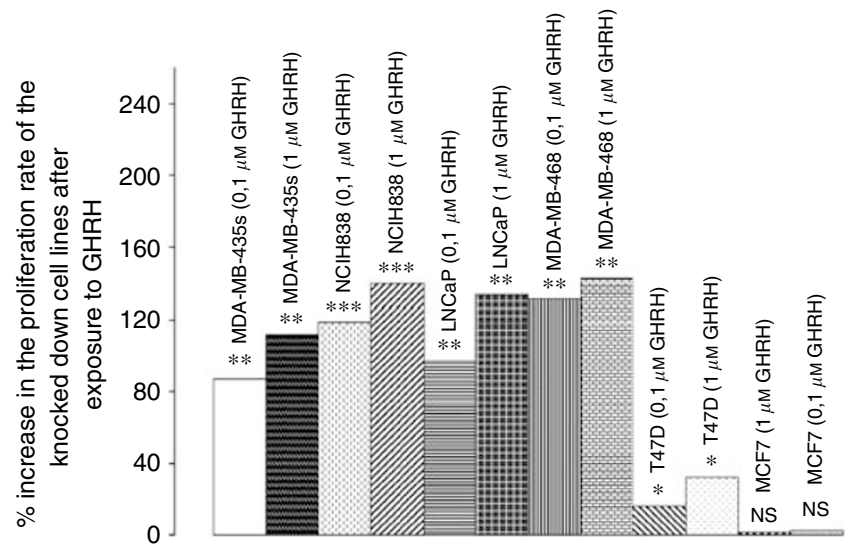

Figure 5 Effect of $\mathrm{GHRH}(\mathrm{I}-29) \mathrm{NH}_{2}$ at 0.1 and I $\mu \mathrm{M}$ concentrations on the proliferation rate of the knocked down siMDA-MB-468, siMDA-MB$435 \mathrm{~s}$ and siT47D breast, siNCl-H838 lung cancer and silNCaP prostate cancer cell lines. MCF-7 breast cancer cell line was used as control. Data are representative of one experiment in triplicate. Percentage increase and significance is expressed vs knocked down cells cultured in the absence of GHRH. $* P<0.05$, $* * P<0.005$, **** $P<0.001$.

changes in the proliferation rate and no toxic effect were found in any cell lines.

\section{Effect of GHRH(1-29) $\mathrm{NH}_{2}$ on the proliferation of the knocked down cancer cell lines in vitro}

When knocked down T47D, MDA-MB-486, MDA-MB-435s breast, LNCaP prostate and NCIH-838 lung cancer cell lines were exposed to $0.1 \mu \mathrm{M}$. Growth hormone-releasing hormone $(1-29) \mathrm{NH}_{2}$ the proliferation rate of the cells was strongly stimulated by $16,132,87$, $97,119 \%$ respectively. The increase on the proliferation rate in response to $1 \mu \mathrm{M}$ GHRH was even greater, being $32,143,112,134$, $140 \%$ respectively. The GHRH did not affect the proliferation rate of MCF-7 breast cancer cell line, which was also transfected with siRNA for GHRH. The results are shown in Figure 5.

Effect of GHRH(1-29) $\mathrm{NH}_{2}$ and GHRH antagonists on the proliferation of cancer cell lines in vitro

T47D, MDA-MB-486, MDA-MB-435s breast, LNCaP prostate and $\mathrm{NCIH}-838$ lung cancer cell lines cultured in vitro were exposed to two concentrations of GHRH $(1-29) \mathrm{NH}_{2}$ and GHRH antagonists MZ-5-156, JMR-132 and MZ-4-71. At the dose of $1 \mu \mathrm{M}$ GHRH $(1-29) \mathrm{NH}_{2}$ did not appreciably influence the proliferation rate of the cells, producing a change only of $1-5 \%$. However GHRH $(1-29) \mathrm{NH}_{2}$ at $0.1 \mu \mathrm{M}$ concentration stimulated of the proliferation rate of the T47D, MDA-MB-468, MDA-MB-435s, LNCaP and NCI H838 cells by $15,17,14,14,16 \%$ respectively. The proliferation of MCF-7 cells (negative control) was not affected by GHRH at 0.1 and $1 \mu \mathrm{M}$ concentrations. The results are shown in Figure 6 .

Growth hormone-releasing hormone antagonist MZ-4-71 at the dose of $0.1 \mu \mathrm{M}$ decreased the proliferation of T47D, MDA-MB-468, MDA-MB-435s, LNCaP and NCI H838 cancer cell lines by 37, 29, $32,29,28 \%$ respectively. The results are presented in Figure 7 . At the dose of $1 \mu \mathrm{M}$ MZ-4-71 produced a somewhat greater inhibition of proliferation of T47D, MDA-MB-468, MDA-MB-435s, LNCaP and NCI H838, the decreases being 39, 35, 36, 35 and $33 \%$ respectively. MZ-4-71 did not affect the proliferation of MCF-7 cells (negative control) (Figure 7).

Similar inhibitory effects on proliferation were obtained with the other two antagonists. Thus GHRH antagonist MZ-5-156 at doses of 0.1 and $1 \mu \mathrm{M}$ reduced the proliferation of T47D, MDA-MB-468, MDA-MB-435s, LNCaP and NCI H838 cancer cell lines by $30-35$, 


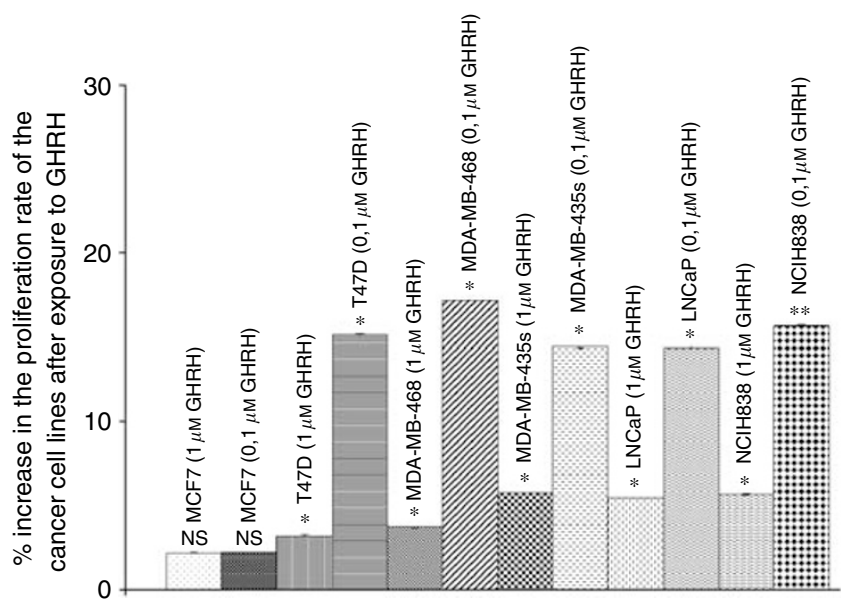

Figure 6 Effect of $\mathrm{GHRH}(\mathrm{I}-29) \mathrm{NH}_{2}$ at concentrations of $0 . \mathrm{I}$ and I $\mu \mathrm{M}$ on the proliferation rate of MCF-7, MDA-MB-468, MDA-MB-435s and $\mathrm{T} 47 \mathrm{D}$ breast, lung $(\mathrm{NCl}-\mathrm{H} 838)$ and prostate $(\mathrm{LNCaP})$ cancer cell lines. Vertical bars represent s.e.m. Data are representative of one experiment in triplicate. Percentage increase and significance are expressed vs cells cultured in the absence of GHRH. $* P<0.05$, $* * P<0.005$.

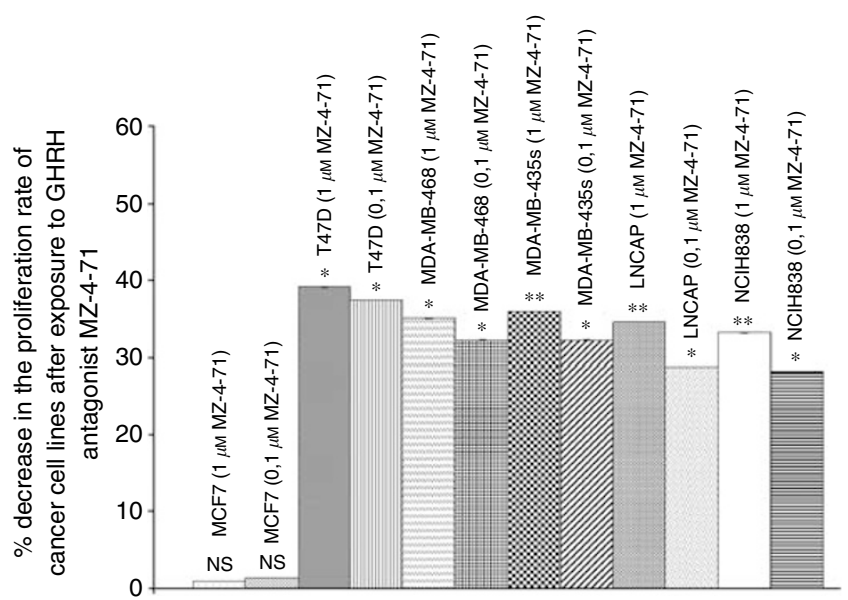

Figure 7 Effect of $\mathrm{GHRH}$ antagonist MZ-4-7I at two concentrations $(0.1, I \mu \mathrm{M})$ on the proliferation rate of MCF-7, MDA-MB-468, MDA-MB435s and T47D breast, lung ( $\mathrm{NCl}-\mathrm{H} 838)$ and prostate (LNCaP) cancer cell lines. Vertical bars represent s.e.m. $* P<0.00$ l. Data are representative of one experiment in triplicate. Percentage increase and significance are expressed vs cells cultured in the absence of the antagonist. $* P<0.05$, $* * P<0.005$.

$28-34,33-40,30-37$, and $30-36 \%$ respectively. Higher doses of the GHRH antagonist again caused a greater inhibition, indicated by the second set of numbers. The results are illustrated in Figure 8.

The proliferation of T47Ds, MDA-MB-468, MDA-MB-435, LNCaP and NCI H838 cancer cell line was also inhibited by $31-37 \%, 26-31 \%, 31-38 \%, 34-41 \%, 37-42 \%$ respectively after exposure to GHRH antagonist JMR-132 at doses of 0.1 and $1 \mu \mathrm{M}$. Higher doses of JMR-132 produced a greater inhibition, indicated by the second set of numbers. The results are shown in Figure 9.

\section{DISCUSSION}

Growth hormone-releasing hormone and the major SV1 of the full length GHRH receptor are expressed in surgical specimens of

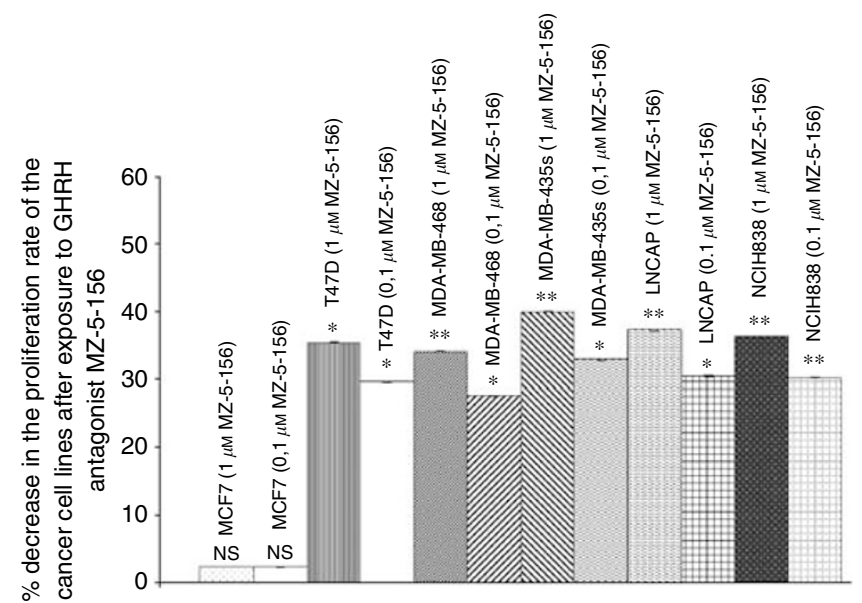

Figure 8 Effect of GHRH antagonist MZ-5-I56 at two concentrations $(0.1, I \mu \mathrm{M})$ on the proliferation rate of MCF-7, MDA-MB-468, MDA-MB435 s and T47D breast, lung ( $\mathrm{NCl}-\mathrm{H} 838)$ and prostate ( $\mathrm{LNCaP})$ cancer cell lines. Vertical bars represent s.e.m. $* P<0.00$ I. Data are representative of one experiment in triplicate \% increase and significance are expressed vs cells cultured in the absence of the antagonist. $* P<0.05$, ${ }^{*} * P<0.005$.

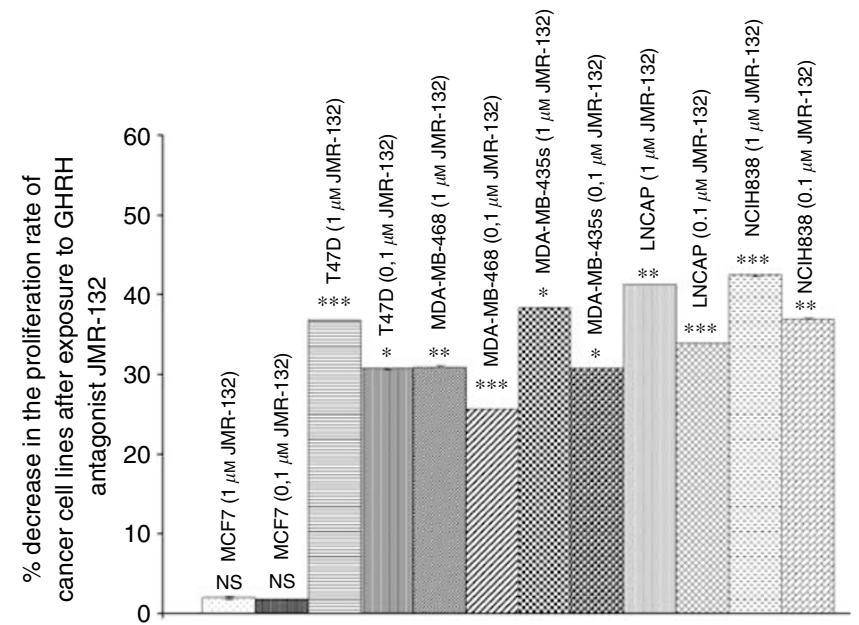

Figure 9 Effect of GHRH antagonist JMR-I32 at two concentrations $(0.1, I \mu \mathrm{M})$ on the proliferation rate of MCF-7, MDA-MB-468, MDA-MB435 s and T47D breast, lung ( $\mathrm{NCl}-\mathrm{H} 838)$ and prostate $(\mathrm{LNCaP})$ cancer cell lines. Vertical bars represent s.e.m. $* P<0.00$ I. Data are representative of one experiment in triplicate. Percentage increase and significance are expressed vs cells cultured in the absence of the antagonist. $* P<0.05$, ** $P<0.005$, **** $P<0.001$

diverse human cancers as well as in a various human cancer cell lines (reviewed in Schally and Varga, 2006). These findings led to the concept that GHRH may function as an autocrine growth factor in many human malignancies.

The precise role of the production of GHRH in the process of tumorigenesis and tumour progression has not been investigated previously. One way to elucidate the role of GHRH in the pathogenesis of cancer is to inhibit its gene expression. In the present study, we first examined the expression of pre-pro GHRH by western blot in human cancer cell lines. The band that reflects the production of the pre-pro GHRH appeared to have a molecular size of $45 \mathrm{kDa}$ on the blots. The facts that this band disappeared in the knocked down cells and could not be detected in the negative control (MCF-7), together with the stimulation of the knocked down cells by exogenous GHRH, indicate that this band represents a precursor of GHRH (Othman et al, 2001). We also tried to 
identify bands corresponding to GHRH $(1-44) \mathrm{NH}_{2}$ by doing western blots for synthetic GHRH $(1-44) \mathrm{NH}_{2}$, but no corresponding signal was detected. Biologically active GHRH was detected by RIA in the conditioned medium of all the cancer cell lines, except for MCF-7.

We then evaluated the expression of the SV1 of GHRH receptor by western blot. The expression of the GHRH and its receptor SV1 in the breast, prostate and non-SCLC cancer cell lines examined suggested the presence of a stimulatory loop in those cells based on GHRH and its receptors. This raised the issue of establishing the role of GHRH in these cancer lines.

Small interfering siRNA for GHRH was used to elucidate the exact function of GHRH. The siRNA for GHRH is a pool of specially designed RNAs for knocking down the expression of human GHRH. After the transfection of the siRNA for GHRH, the proliferation rate of the MDA-MB-468 and MDA-MB-435s cancer lines was dramatically decreased by 85.1 and $85.9 \%$ respectively. The decreased proliferation, in combination with the fact that the silencing of the gene expression for GHRH lasts only for limited cell passages, did not allow us to isolate protein from these cells for western blot analysis during early cell passages. The isolation of the proteins obtained in late cell passages showed that the silencing of the GHRH gene expression was less effective in these passages.

In the case of the T47D cells the proliferation rate was decreased by $28.3 \%$. The T47D cell line has the highest expression of SV-1 of the GHRH receptor with its ligand-dependent and independent activity. The inhibition of the gene expression for GHRH in T47D breast cancer cell line did not have the potent antiproliferative effect found in the other two breast cancer cell lines (MDA-MB-468 and MDA-MB-435S), possibly because the ligand independent activity of the SV1 continued to enhance the proliferation rate of the T47D cells (Kiaris et al, 2003; Barabutis et al, 2007).

Prostate cancer cell line LNCaP and non-SCLC cell line NCI H838 showed decreases in proliferation rates of 51.8 and $48.4 \%$ respectively after the inhibition of the GHRH gene expression. Both these cancer cell lines express SV-1 and because of its ligand-independent activity their proliferation rate continued to be stimulated in the absence of the intrinsic production of the GHRH.

The possible presence of GHRH and other related peptides such as VIP in the media of the cells that were tested cannot be excluded. Thus GHRH could keep acting as a growth factor and the proliferation rate of all the cancer cell lines that were assayed may not reflect the conditions of a total absence of GHRH.

MCF-7 breast cancer cells were also transfected with siRNA for knocking down the GHRH gene. This was done to test for any possible toxic effects, which could be related to the presence of the siRNA because MCF-7 line does not produce GHRH, its behaviour after the transfection had to remain the same. The transfection of the siRNA for GHRH did not influence the proliferation rate of the MCF-7 cells. Consequently the decreased proliferation rate of the breast, prostate and non-SCLC after the transfection was not due to toxic effects. The transfection of control siRNA did not lead to any changes in the proliferation of these cells.

In addition, we exposed the knocked down MDA-MB-468, MDA-MB-435s, T47D, LNCaP and NCI-H838 cancer cell lines to two different concentrations of GHRH $(1-29) \mathrm{NH}_{2}$. The proliferation rate of the cells was strongly stimulated by the addition of exogenous GHRH, not only at the concentration of $0.1 \mu \mathrm{m}$ but also at a concentration of $1 \mu \mathrm{m}$. The silenced cancer cell lines, lacking intrinsic GHRH, were still able to respond to exogenous GHRH, confirming the absence of possible toxic effects related to the transfections. MCF7 cells transfected with siRNA for GHRH were also exposed to GHRH. The proliferation rate of the transfected MCF7 cells was not influenced by the addition of the exogenous GHRH.

We also investigated the effect of GHRH and GHRH antagonists at two concentrations in MCF-7, MDA-MB-468, T47D, MDA-MB435s, LNCaP and NCI H838 cancer cell lines. The proliferation rate of the MCF-7 breast cancer cell line was not influenced by the presence of the GHRH or its antagonists, since MCF-7 does not express specific receptors for GHRH. At the dose of $0.1 \mu \mathrm{M} \mathrm{GHRH}$ stimulated the proliferation rate of the cancer cell lines by $15-17 \%$. However, at a dose of $1 \mu \mathrm{M}$ GHRH did not influence significantly the proliferation rate of cell lines. Thus, because of the possible presence of GHRH or other related peptides in the medium, as well as of GHRH secreted by the cells, it is likely that the corresponding signalling pathways were saturated after exposure to $1 \mu \mathrm{M}$ GHRH.

These breast, lung and prostate cancer cell lines were also exposed in vitro to two concentrations of GHRH antagonists MZ-4-71, MZ-5-156 and JMR-132. At concentrations of 0.1 and $1 \mu \mathrm{M}$, the proliferation rate of these cells was decreased by $26-37 \%$ and $31-42 \%$ respectively.

The present study demonstrates the tumorigenic effect of GHRH in the human experimental tumour cell lines representative of leading cancers. Our work supports the concept that GHRH functions as growth factor in human cancers.

\section{ACKNOWLEDGEMENTS}

The work described in this paper was supported by the Medical Research Service of the Veterans Affairs Department and a grant from Zentaris AG, Frankfurt on Main, Germany to South Florida Veterans Affairs Foundation for Research and Education and University of Miami Miller School of Medicine Departments of Pathology and Medicine Division of Heratology/Oncology (all to AVS). NB is a recipient of a fellowship from the Alexander S Onassis Public Benefit Foundation. This paper is dedicated to Eleni, Asteria and Aristides Barabutis for inspiring one of us (NB).

\section{REFERENCES}

Barabutis N, Tsellou E, Schally AV, Kouloheri S, Kalofoutis A, Kiaris H (2007) Stimulation of proliferation of MCF-7 breast cancer cells by a transfected splice variant of growth hormone-releasing hormone receptor. Proc Natl Acad Sci USA 104: 5575-5759

Braczkowski R, Schally AV, Plonowski A, Varga JL, Groot K, Krupa M, Armatis P (2002) Inhibition of proliferation in human MNNG/HOS osteosarcoma and SK-ES-1 Ewing sarcoma cell lines in vitro and in vivo by antagonists of growth hormone-releasing hormone: effects on insulinlike growth factor II. Cancer 95: 1735-1745

Buchholz S, Schally AV, Engel JB, Hohla F, Heinrich E, Koester F, Varga JL, Halmos G (2007) Potentiation of mammary cancer inhibition by combination of antagonists of growth hormone-releasing hormone with docetaxel. Proc Natl Acad Sci USA 104: 1943-1946

Busto R, Schally AV, Varga JL, Garcia-Fernandez MO, Groot K, Armatis P, Szepeshazi K (2002) The expression of growth hormone-releasing hormone (GHRH) and splice variants of its receptor in human gastroenteropancreatic carcinomas. Proc Natl Acad Sci USA 99: $11866-11871$

Chatzistamou I, Schally AV, Varga JL, Groot K, Armatis P, Bajo AM (2001) Inhibition of growth and reduction in tumourigenicity of UCI-107 ovarian cancer by antagonists of growth hormone-releasing hormone and vasoactive intestinal peptide. J Cancer Res Clin Oncol 127: 645-652 Christodoulou C, Schally AV, Chatzistamou I, Kondi-Pafiti A, Lamnissou K, Kouloheri S, Kalofoutis A, Kiaris H (2006) Expression of growth hormone-releasing hormone (GHRH) and splice variant of GHRH receptors in normal mouse tissues. Regul Pept 136: 105-108 
Knocking down gene expression for GHRH

$N$ Barabutis and AV Schally

1796

Engel JB, Keller G, Schally AV, Toller GL, Groot K, Havt A, Armatis P, Zarandi M, Varga JL, Halmos G (2005) Inhibition of growth of experimental human endometrial cancer by an antagonist of growth hormone-releasing hormone. J Clin Endocrinol Metab 90: $3614-3621$

Gaylinn BD, Harrison JK, Zysk JR, Lyons CE, Lynch KR, Thorner MO (1993) Molecular cloning and expression of a human anterior pituitary receptor for growth hormone-releasing hormone. Mol Endocrinol 7: 77-84

Halmos G, Schally AV, Varga JL, Plonowski A, Rekasi Z, Czompoly T (2000) Human renal cell carcinoma expresses distinct binding sites for growth hormone-releasing hormone. Proc Natl Acad Sci USA 97: $10555-10560$

Havt A, Schally AV, Halmos G, Varga JL, Toller GL, Horvath JE, Szepeshazi K, Koster F, Kovitz K, Groot K, Zarandi M, Kanashiro CA (2005) The expression of the pituitary growth hormone-releasing hormone receptor and its splice variants in normal and neoplastic human tissues. Proc Natl Acad Sci USA 102: 17424-17429

Hohla F, Schally AV, Szepeshazi K, Varga JL, Buchholz S, Köster F, Heinrich E, Halmos G, Rick FG, Kannadka C, Datz C, Kanashiro CA (2006) Synergistic inhibition of growth of lung carcinomas by antagonists of growth hormone-releasing hormone in combination with docetaxel. Proc Natl Acad Sci USA 103: 14513-14518

Jaeger LB, Banks WA, Varga JL, Schally AV (2005) Antagonists of growth hormone-releasing hormone cross the blood-brain barrier: a potential applicability to treatment of brain tumours. Proc Natl Acad Sci USA 102: $12495-12500$

Kiaris H, Chatzistamou I, Schally AV, Halmos G, Varga JL, Koutselini H, Kalofoutis A (2003) Ligand-dependent and -independent effects of splice variant 1 of growth hormone-releasing hormone receptor. Proc Natl Acad Sci USA 100: 9512 - 9517

Macaulay VM (1992) Insulin-like growth factors and cancer. Br J Cancer 65: $311-320$
Mayo KE (1992) Molecular cloning and expression of a pituitary-specific receptor for growth hormone-releasing hormone. Mol Endocrinol 10: $1734-1744$

Othman NH, Ezzat S, Kovacs K, Hoevath E, Poulin E, Smyth HS, Asa SL (2001) Growth hormone-releasing hormone (GHRH) and GHRH receptor (GHRH-R) isoform expression in ectopic acromegaly. Clinical Endocrinol 55: $135-149$

Rekasi Z, Czompoly T, Schally AV, Halmos G (2000) Isolation and sequencing of cDNAs for splice variants of growth hormone-releasing hormone receptors from human cancers. Proc Natl Acad Sci USA 97: 10561-10566

Schally AV, Varga JL (2006) Antagonist of growth hormone - releasing hormone in oncology. Combin Chem and HighThroughput Screen 9: $163-170$

Stangelberger A, Schally AV, Zarandi M, Heinrich E, Groot K, Havt A, Kanashiro CA, Varga JL, Halmos G (2007) The combination of antagonists of LHRH with antagonists of GHRH improves inhibition of androgen sensitive MDA-PCa-2b and $\mathrm{LnCaP}-35$ prostate cancers. Prostate 67: 1339-1353

Szepeshazi K, Schally AV, Groot K, Armatis P, Halmos G, Herbert F, Szende B, Varga JL, Zarandi M (2000) Antagonists of growth hormone-releasing hormone (GH-RH) inhibit IGF-II production and growth of HT-29 human colon cancers. Br J Cancer 82: 1724-17231

Toller GL, Horvath JE, Schally AV, Halmos G, Varga JL, Groot K, Chism D, Zarandi M (2004) Development of a polyclonal antiserum for the detection of the isoforms of the receptors for human growth hormone-releasing hormone on tumours. Proc Natl Acad Sci USA 101: 15160-15165

Westley BR, May FE (1995) Insulin-like growth factors: the unrecognized oncogenes. Br J Cancer 72: $1065-1066$

Zarandi M, Varga JL, Schally AV, Horvath JE, Toller GL, Kovacs M, Letsch M, Groot K, Armatis P, Halmos G (2006) Lipopeptide antagonists of growth hormone-releasing hormone with improved antitumour activities. Proc Natl Acad Sci USA 103: 4610-4615 